\title{
Intersections
}

Canadian Journal of Music

Revue canadienne de musique

\section{Gail Dixon. 2004. The Music of Harry Freedman. Toronto: University of Toronto Press, viii, 190 pp. ISBN 0-8020-8964-X (hardcover)}

\section{Andrew M. Zinck}

Volume 25, numéro 1-2, 2005

URI : https://id.erudit.org/iderudit/1013317ar

DOI : https://doi.org/10.7202/1013317ar

Aller au sommaire du numéro

Éditeur(s)

Canadian University Music Society / Société de musique des universités canadiennes

ISSN

1911-0146 (imprimé)

1918-512X (numérique)

Découvrir la revue

Citer ce compte rendu

Zinck, A. M. (2005). Compte rendu de [Gail Dixon. 2004. The Music of Harry

Freedman. Toronto: University of Toronto Press, viii, $190 \mathrm{pp}$. ISBN

0-8020-8964-X (hardcover)]. Intersections, 25(1-2), 249-251.

https://doi.org/10.7202/1013317ar

Copyright @ Canadian University Music Society / Société de musique des universités canadiennes, 2005
Ce document est protégé par la loi sur le droit d'auteur. L'utilisation des services d'Érudit (y compris la reproduction) est assujettie à sa politique d'utilisation que vous pouvez consulter en ligne.

https://apropos.erudit.org/fr/usagers/politique-dutilisation/ 
Mawer, Deborah. 1997. Darius Milhaud, Modality and Structure in Music of the 1920s. Aldershot : Ashgate.

Milhaud, Darius. 1987. Ma vie heureuse. Paris : Belfond.

François de Médicis

Gail Dixon. 2004. The Music of Harry Freedman. Toronto: University of Toronto Press. viii, 190 pp. ISBN 0-8020-8964-X (hardcover).

With the death of Harry Freedman in the fall of 2005, Canada's musical community mourned the loss of one of its most prolific composers, a man who left an eclectic musical legacy of over 175 diverse compositions, including vocal and choral pieces, chamber and orchestral works, and music for film and stage. To our national shame, despite Freedman's recognized status as a key figure in Canadian classical music for over half a century, much of his compositional output remains unfamiliar to many in this country. Gail Dixon's book The Music of Harry Freedman provides the first detailed examination of his oeuvre and, as such, represents an important step forward in highlighting this large body of influential works.

The book is comprised of seven chapters written in an accessible style. The opening chapter outlines the scope of the investigation, discusses the challenge of selecting works for analysis from the composer's extensive catalogue, and explains the analytic conventions used. The subsequent five chapters provide the core discussion of the repertoire, for which Dixon constructs an engaging narrative of the composer's personal and creative journey. She presents a chronology of Freedman's stylistic development through an examination of over fifty representative works and including nearly 100 musical examples, some drawn directly from autograph scores. The final chapter identifies the recurring patterns in Freedman's work that provide a sense of thematic coherence over 56 years of the composer's career, and supplements the picture with a discussion of the attitudes and interests that profoundly shaped his compositional persona. The accompanying notes for each chapter provide valuable insights into individual works and how they took shape. Since at times they contain evidence of consultations that took place between Dixon and Freedman on a number of issues, they also provide a space to share the composer's own perspective. A chronological list of Freedman's works (up to 1997) provides a useful concluding reference.

The outline of Freedman's professional life begins with an image of a composer who was intensely conscious of living in the shadow not just of his teacher and mentor, John Weinzweig, but of such twentieth-century musical legends as Stravinsky, Bartók, Hindemith, and Prokofiev. Dixon presents Freedman's early works in part as evidence of his musical indebtedness to these composers. This establishes a foundation for the stylistic changes that would soon follow: through the 1960s, Freedman embarked on a deliberate path to forge a new compositional voice, re-assessing his attitudes toward the 
dodecaphonic approach he had first learned and exploring alternative techniques and sources of musical materials.

Dixon traces Freedman's output from 1960 to 1997 (the end point of her study) as the composer's lengthy search for a personal compositional language, his emancipation from his musical idols and the legacy of his musical past, and his eventual maturation. She accomplishes this primarily by presenting recurring patterns of mediation that involve three fundamental musical oppositions. The first is an opposition between the control offered by formal systems (e.g., various types of serialism and mathematical structures or puzzles) and the freedom offered by improvisation, aleatoric procedures, and large sound masses. The second opposition involves the boundaries between art music and jazz, which are explored frequently in Freedman's works. The third encompasses the tension between stylistic unity and stylistic plurality, both within the composer's oeuvre and within a single work; as he became more comfortable with various styles and techniques, he freely moved among them and combined them with confidence.

Dixon's intent with this study was not simply to raise awareness of Freedman's music, although that was clearly a significant and justifiable impetus. Rather, her aim was to construct a detailed narrative of a compositional and stylistic journey while highlighting the threads of continuity that are woven throughout Freedman's musical output-a delicate balance to maintain. Throughout the book the primary focus is an examination of the music itself, with biographical material used only occasionally to provide an essential context for key pieces. The paucity of biographical information might be considered by some as problematic in what is effectively a foundational study (indeed, few readers would be intimately familiar with the details of the composer's life), but its dearth can perhaps be justified by Dixon's unwavering desire to address specific issues of repertoire and style without distraction. Instead of presenting them simply as illustrations of particular biographical stages, the analyses themselves are left to tell the tale of the composer's stylistic development. Occasionally, however, although some of Freedman's stylistic and technical experiments are traced through the book and receive special analytical attention, it is not always clear what specific motivation or influences led to them.

Many researchers of Canadian music face a common challenge: to present analyses of compositions that remain largely unfamiliar to the majority of readers. While a Beethoven or Mozart scholar can often assume that the reader will have a passing familiarity with the music under study (or at least relatively easy access to it via scores and recordings), the researcher of Canadian classical repertoire frequently must accept the burden of explaining in words the essence of musical ideas whose aural reality will never have been experienced by the reader. Furthermore, in writing a monograph that provides the first large-scale study of a composer's works, the author accepts the additional responsibility of constructing a coherent and meaningful initial 
narrative from a vast body of works. This involves balancing the competing needs of depth and breadth of coverage while remaining mindful that the musical descriptions will necessarily serve as introductions to the works for many readers. For the most part, Dixon manages this extremely difficult task with ease. Her series of short analytical summaries serves to foreground selected key patterns in Freedman's changing style in an efficient and engaging manner. By occasionally drawing upon Freedman's compositional sketches and her direct discussions with the composer, Dixon also illuminates issues of compositional process (one area that could have been given more attention in the present study). Although she does not single out any one composition as a focal point, two landmark works-the ballet Rose Latulippe (1967) and the orchestral/choral work Borealis (1987)-are subjected to slightly more substantial analyses than the others, and, as a pair, they highlight the distance travelled in the thirty-year span encompassing the maturation of the composer's style.

The Music of Harry Freedman is a significant and welcome contribution to modern Canadian music scholarship. One could argue that such a comment is a cliché in a field that is arguably still in its infancy and sorely needs more such publications, but the rigour with which Gail Dixon tackles and meaningfully summarizes such an expansive and diverse repertoire as Freedman's justifies particular recognition for her book. Historians of Canadian music often become "archaeologists" of our recent and living musical heritage, attempting to put together the myriad pieces of a complex puzzle that describes our nation's musical identity. This study of Freedman's compositional journey adds some crucial pieces to that puzzle, and with it the larger narrative of an influential generation of Canadian composers is becoming gradually more apparent. 